\title{
In-vitro studies of Bryophyllum pinnatum Crude Extract on Blood Coagulation Indices: An Investigation on its Traditional Medicine Use
}

\author{
Promise Madu Emeka ${ }^{1,2, *}$
}

\section{Promise Madu Emeka ${ }^{1,2, *}$ \\ 'Department of Pharmaceutical Sciences, College of Clinical Pharmacy, King Faisal University, Hofuf, SAUDI ARABIA. 2Department of Pharmacology, College of Medicine, University of Lagos-Lagos, NIGERIA. \\ Correspondence}

Promise Madu Emeka

Department of Pharmaceutical Sciences, College of Clinical Pharmacy, King Faisal University, Hofuf, SAUDI ARABIA.

Phone no: +966503239033

Email id: pemeka@kfu.edu.sa

History

- Submission Date: 17-05-2021.

- Review completed: 16-07-2021.

- Accepted Date: 30-08-2021

DOI : 10.5530/pres.13.4.21

Article Available online

http://www.phcogres.com

\section{Copyright}

(c) 2021 Phcog.Net. This is an openaccess article distributed under the terms of the Creative Commons Attribution 4.0 International license.

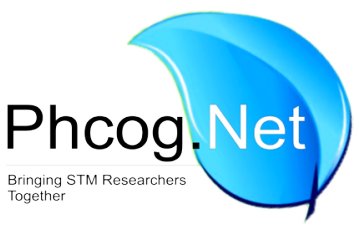

\begin{abstract}
Background: Bryophyllum pinnatum extract is used by African natives to stop epistaxis [nose bleeding], postpartum bleeding as well as fresh wounds bleeding. Aim: This study was carried out in order to evaluate the coagulant effects and properties of crude B.pinnatum extract using in-vitro blood coagulation screening tests. Materials and Methods: Healthy volunteers were used for the study and the following tests were performed: prothrombin time (PT), Partial Thromboplastin Time with Kaolin (PTTK), Thrombin Time (TT), Euglobulin Lysis Time (ELT), bleeding time (BT) and whole blood coagulation time (WBCT). Blood samples were collected from adult male and female volunteers by trained phlebotomist from the thumb and venous puncture depending on the type of coagulation test. Results: $B$. pinnatum extract produced a profound decreased in PT, PTTK, TT and ELT times which were concentration dependent. Extract concentrations of $84 \mathrm{mg} / \mathrm{ml}$ produced a highly significant reductions $(p<0.05)$ in PT, PTTK and TT with $1.68 \pm 0.16,7.1 \pm 0.28,1.06 \pm 0.19 \mathrm{sec}$ respectively. Whole blood coagulation time was decreased by $84 \mathrm{mg} / \mathrm{ml}$ concentration but not significantly. Results also showed that bleeding time was significantly reduced by $84 \mathrm{mg} / \mathrm{ml}$ concentration of $B$. pinnatum extract. The effect on plasma showed that the extract had coagulant property without the addition of activating agent to the platelet-poor plasma. Conclusion: This investigation confirms the traditional use of this plant extract in the treatment of bleeding episodes, indicating that the extract has blood coagulant properties and therefore could potentially be used in fibrinogen abnormality, deficiency of factors XII, XI, IX, or VIII, heparin in blood.

Key words: Bryophyllum pinnatum, Coagulation, Blood, Extract, Plasma, Bleeding.
\end{abstract}

\section{INTRODUCTION}

Herbal remedies are used worldwide for the treatment of variety of diseases, including blood-related disorders. They are often perceived as effective and safe because they are of natural origin, ${ }^{[1]}$ and their uses are reported to be on the rise. ${ }^{[2]}$ It is reported that nearly one in six adults taking prescription drugs in the United States is concomitantly using at least one herbal remedy. ${ }^{[3,4]}$ Medicinal plants are widely used in Nigeria as alternatives to conventional medicines, ${ }^{[5]}$ and despite the availability of modern medicines in the treatment of ailments; people still continue to resort to the use of herbal medicines. ${ }^{[6]} \mathrm{WHO},{ }^{[7]}$ reports that $85 \%$ of the sub-Saharan Africa is still dependant on the use of herbal medicinal preparation. The economic situation, high cost of modern drugs and easy accessibility to traditional medicine practitioners drives the trend to traditional medicine. ${ }^{[8]}$ Efforts have been made by various workers to discover natural products which have antiplatelet, ${ }^{[9]}$ anticoagulant, ${ }^{[10]}$ antithrombotic, ${ }^{[11]}$ and thrombolytic activity. Coagulation is a complex process by which blood forms clots. It is an important part of hemostasis. ${ }^{[12]}$ Disorders of coagulation can lead to increased risk of bleeding (hemorrhage) or clotting (thrombosis). In patients with advanced liver disease, bleeding and thrombosis are dangerous complications particularly in those challenged by infection or require surgery. ${ }^{[12]}$ Reports have shown that the products of traditionally used plants such as $B$. pinnatum promote healing in experimental animals. ${ }^{[13]}$ One of the most popular and commonly used herbal preparations in Africa is Bryophyllum pinnatum (Crassulaceae). B. pinnatum was first introduced in 1970 at a German complementary/alternative medicine (CAM) centre as treatment for premature labour. ${ }^{[14]}$ Clinical outcome in terms of inhibitory activity of the plant product was reported to be similar to those of Fenoterol with its administration reportedly to being a bonus during delivery if contractions are too strong, frequent or painful. ${ }^{[14]}$ It is a succulent perennial herb $0.60-1.20 \mathrm{~m}$ high, of Madagascan origin, but spread as an anthropogenic plant tropically. It is naturalized in the territories of the region from Sierra Leone to Southern Nigeria, ${ }^{[15]}$ but has not

Cite this article: Emeka PM. In-vitro studies of Bryophyllum pinnatum Crude Extract on Blood Coagulation Indices: An Investigation on its Traditional Medicine Use. Pharmacog Res. 2021;13(4): 268-73. 
penetrated into the drier states. The plant is used in folkloric medicine in tropical Africa, tropical America, India, China and Australia. ${ }^{[16]}$ The character of this plant has naturally attracted a lot of different descriptive English names, like, "Never - die, resurrection plant, air-plant, life plant due to the viviparous and tenacious properties of the plant. These generic names appear also to allude to the leaf vivipary: bruo, from Greek meaning, to be full of, or to burst forth, and 'phullon', a leaf. ${ }^{[17]}$

The leaves and bark of $B$. pinnatum serve as bitter tonic, an astringent to the bowels, which is useful in the treatment of diarrhea and vomiting. ${ }^{[18,19]}$ In traditional medicine, the leave extracts of the plant have been used as antimicrobials, ${ }^{[20]}$ antihypertensive. ${ }^{[21,22]}$ The leaf extracts have also been shown to have neurosedative and muscle relaxant properties by Yemitan and Salahdeen. ${ }^{[23]}$ In East Africa, the slightly heated leaves (heated over fire) are rubbed over the body to treat stiff joint and rheumatism. ${ }^{[15]}$ Alkaloids and saponins are present in the aqueous and alcoholic extracts of leaves and lectins in the juice from the fresh leaves. ${ }^{[24]}$ The green callus of the plant contains malic acid, quinones and tocopherol. ${ }^{[25]}$ The plant is reported to be rich in micro and macro elements, vitamins, calcium, phosphorus, ascorbic acid, insulin. ${ }^{[26]}$ The wide range use traditionally, of the plant justifies its being called "life plant", "resurrection plant", or "good luck".[27] Most of the users of B. pinnatum herbal preparations take it as decoction and in treatment of certain diseases such as wound, bruises and nose bleeding. Its effects on blood coagulation have not been investigated since the plant is also used in stopping bleeding and in wounds. Therefore, the present work was undertaken to evaluate the coagulant effects/properties of $B$. pinnatum crude extract using various in-vitro tests.

\section{MATERIALS AND METHODS}

\section{Collection of Plant}

Bryophyllum pinnatum plant was collected from Ilorin, Kwara State of Nigeria. A group of research Scientists in the Department of Pharmacognosy, Faculty of Pharmacy, University of Lagos, identified the plant.

\section{Preparation of Extract}

$18.90 \mathrm{~g}$ of fresh B. pinnatum leaves were weighed out and squeezed to extract the juice thoroughly from the plant. The following procedure was used for the calculation of the concentration of the extract.

$$
\text { Concentration }=\frac{\text { Initial weight of leaves }- \text { Final weight of leaves }}{\text { Final volume of extract }}
$$

Where, Initial weight of leaves $=18.90 \mathrm{~g}$

Final weight of leaves extract $=12.70 \mathrm{~g}$

Final volume of extract $=14.92 \mathrm{ml}$

$$
\text { Concentration }=\frac{18.90-12.70}{14.92}=\frac{6.11}{14.92}=0.41 \mathrm{~g} / \mathrm{ml}=415.5 \mathrm{mg} / \mathrm{ml}
$$

Volumes and concentrations of extract used where as follows $0.05 \mathrm{ml}$ $(21 \mathrm{mg} / \mathrm{ml}), 0.1 \mathrm{ml}(42 \mathrm{mg} / \mathrm{ml})$ and $0.2 \mathrm{ml}(84 \mathrm{mg} / \mathrm{ml})$.

\section{Ethical Issues}

Students' volunteers (18-30 years) male and female were used for the study who indicated their willingness to participate freely to advance Science. Their informed consent was obtained according to the Declaration of Helsinki. Authorization to conduct the study was obtained from the Deanship of Basic Medical Sciences, Department of Pharmacology, College of Medicine Ethical Committee, The University of Lagos, Idi-araba, Lagos. (980702012/2002). Volunteers were accepted based on their good general health, which included normal blood count and physiological parameters. Blood samples which appeared haemolysed and turbid were discarded and those who were icteric according to the examining physician were not allowed to participate in the study.

\section{Blood Sample collection}

A phlebotomist, assisted in blood collection, collected Blood samples. Different methods were used in the collection of blood samples depending on the type of test, but most were collected by finger pricking and tests were all in-vitro.

\section{Prothrombin Time (PT)}

The method of Quick, ${ }^{[28]}$ was used in determining PT. To a $0.05 \mathrm{ml}$ $(21 \mathrm{mg} / \mathrm{ml})$ of fresh $B$. pinnatum extract was added $0.1 \mathrm{ml}$ of normal plasma and $0.2 \mathrm{ml}$ of calcium thromboplastin reagent. The time of appearance of fibrin clot was recorded as PT. Another experiment was set up with the same parameters as above but with different concentrations of fresh B. pinnatum extract. For the control experiment, $0.05 \mathrm{ml}$ of normal saline was used in place of $B$. pinnatum extract.

\section{Partial Thromboplastin time with kaolin (PTTK)}

Into a glass tube, containing $0.1 \mathrm{ml}$ of normal plasma in a water bath was added $0.2 \mathrm{ml}$ of a well -shaken kaolin phospholipids mixture. The plasma kaolin phospholipids mixture was left in the water bath at $37^{\circ} \mathrm{C}$ with occasional shaking. The procedure was timed with the aid of a stopwatch. $0.1 \mathrm{ml}$ of calcium chloride solution and $0.05 \mathrm{ml}(21 \mathrm{mg} / \mathrm{ml})$ of the extract of $B$. pinnatum were added to the mixture $10 \mathrm{~min}$ later. The time of appearance of a fibrin clot was recorded (PTTK) with the aid of a stopwatch. In the control experiment, $0.05 \mathrm{ml}$ of normal saline was used in place of $B$. pinnatum extract. ${ }^{[29,30]}$

\section{Thrombin Time (TT)}

Determination of Thrombin time was according to the method of Hardisty and Ingram. ${ }^{[31]}$ To a mixture of $0.05 \mathrm{ml}(21 \mathrm{mg} / \mathrm{ml})$ fresh B. pinnatum extract and $0.1 \mathrm{ml}$ normal plasma in a clotting tube was added $0.2 \mathrm{ml}$ of thrombin solution and the time of appearance of a fibrin clot was recorded as TT. $0.05 \mathrm{ml}$ of normal saline was used in place of the B. pinnatum extract in the control experiment.

\section{Euglobulin Lysis Test (ELT)}

A slightly modified method of Blix, ${ }^{[32]}$ was used in the determination of ELT. Three centrifuge tubes were set up. The first had $0.5 \mathrm{ml}$ fresh normal plasma, the second is a mixture of $0.2 \mathrm{ml}(84 \mathrm{mg} / \mathrm{ml})$ of B. pinnatum extract and $0.5 \mathrm{ml}$ of normal plasma while the third, $0.1 \mathrm{ml}$ of normal saline mixed with $0.5 \mathrm{ml}$ normal plasma. Into each of these was added $9.01 \mathrm{ml}$ distilled water and $0.1 \mathrm{ml}$ of $1 \%$ of acetic acid and the set up was kept at $4^{\circ} \mathrm{C}$ for $30 \mathrm{~min}$. Each tube was centrifuged, solution carefully decanted and $0.5 \mathrm{ml}$ of borate saline buffer added to the deposit. The mixture was kept at $37^{\circ} \mathrm{C}$ adding $0.5 \mathrm{ml}$ of calcium chloride solution after noting the time of formation of a clot, time of complete lysis of the clot was recorded (ELT).

\section{Whole Blood Coagulation Time}

The modified method of Lee and White as described by de Brito Sousa et al. ${ }^{[33]}$ Was use in this. evaluation. $1 \mathrm{ml}$ each of second stream blood was placed in four cleaned dry standard test tube in a $37^{\circ} \mathrm{C}$ water bath. Each tube was tilted $1 / 2$ minute $(30 \mathrm{sec}$ ) Until they can be inverted without spilling any blood and the time from collecting the blood to tilting for each tube, was noted using a stopwatch. The coagulation time for each tube was recorded separately and the average of the 3 tests was taken as the coagulation time. In another experiment, $0.05 \mathrm{ml}, 0.1 \mathrm{ml}$ and $0.2 \mathrm{ml}$ of 
the test extract (B. pinnatum), representing 21,42 and $84 \mathrm{mg} / \mathrm{ml} \mathrm{respec-}$ tively were added into 3 different standard test tubes each containing $1 \mathrm{ml}$ of blood and using the same method of blood sample collection and the time for clotting was noted.

\section{Bleeding Time (BT)}

Bleeding time was observed at $30 \mathrm{sec}$ intervals from a thumb prick, blood was absorbed gently by touching the blood with filter paper, until bleeding ceased. The blots were collected in series along the edge of the filter paper; the numbers of blots divided by 2 gave the bleeding time (BT). Bleeding time was carried out to check the effect of $B$. pinnatum extract on the pricked thumb with a lancet. The fresh crude $B$. pinnatum extract was immediately applied on the pricked thumb and the above procedure was followed and BT was recorded.

\section{Statistical analysis}

Data is presented as mean \pm SEM and the number of repeats is denoted as n. Statistical analysis was performed using GraphPad Prism software version 8.2 (San Diego, CA, USA). Comparisons were done between control and B. pinnatum crude extract treated groups using the one-way analysis of variance. The differences between the individual test groups were determined using the Tukey's multiple comparison test, hence, $p<0.05$ was considered statistically significant.

\section{RESULTS}

\section{Prothrombin Time (PT)}

In this investigation, the results as presented in Table 1 show that with different extract concentrations of B. pinnatum of $21 \mathrm{mg} / \mathrm{ml}$ and $42 \mathrm{mg} / \mathrm{ml}$ gave a highly significant reduced PT ( $p<0.05$ ) $4.9 \pm 0.37$ and $1.68 \pm 0.16$ sec respectively, normal range for PT being 10-14secs. Table 1). The prothrombin time test is a non - specific indicator of the extrinsic blood coagulation mechanism. Deficiencies of Prothrombin and factors, V, VII and $\mathrm{X}$ give rise to a prolonged time, as well as the presence of heparin in the blood and hypofibrinogenaemia

\section{Partial Thromboplastin Time with Kaolin (PTTK)}

Partial Thromboplastin Time with Kaolin (PTTK) results show that with varying concentrations of extract B. pinnatum; $21 \mathrm{mg} / \mathrm{ml}$ and $42 \mathrm{mg} / \mathrm{ml}$ gave a highly significant reduced PTTK $(p<0.05)$ respectively (Table 1$)$.

\section{Thrombin Time (TT)}

The results obtained for Thrombin Time (TT) in this study, showed that 21 and $42 \mathrm{mg} / \mathrm{ml}$ of the extract of $B$. pinnatum also produced a highly significant decreased $(p<0.05)$ TT compared with the control with all concentrations used (Table 1).

\section{Euglobulin Lysis Time (ELT)}

The result obtained from this investigation shows that concentrations of $84 \mathrm{mg} / \mathrm{ml}$ concentration of $B$. pinnatum extract produced a significant reduction $(p<0.05)$ in ELT (Table 1$)$.

\section{Whole Blood Coagulation Time}

The results for whole blood coagulation time as shown in Figure 1 indicated that the effect of extract of B.pinnatum on whole blood coagulation compared to the normal time was not significantly reduced. The extract in concentrations of $84 \mathrm{mg} / \mathrm{ml}$ was however reduced by 0.36 mins. In this study, when varying volumes $0.05 \mathrm{ml}, 0.1 \mathrm{ml}$ and $0.2 \mathrm{ml}$ of Bryophyllum pinnatum extract representing 21,42 and $84 \mathrm{mg} / \mathrm{ml}$ concentrations were added to plasma only gave concentration dependent reductions in minutes respectively. Inferring that the extract has coagulant properties independent of the activating agents (Figure 1).

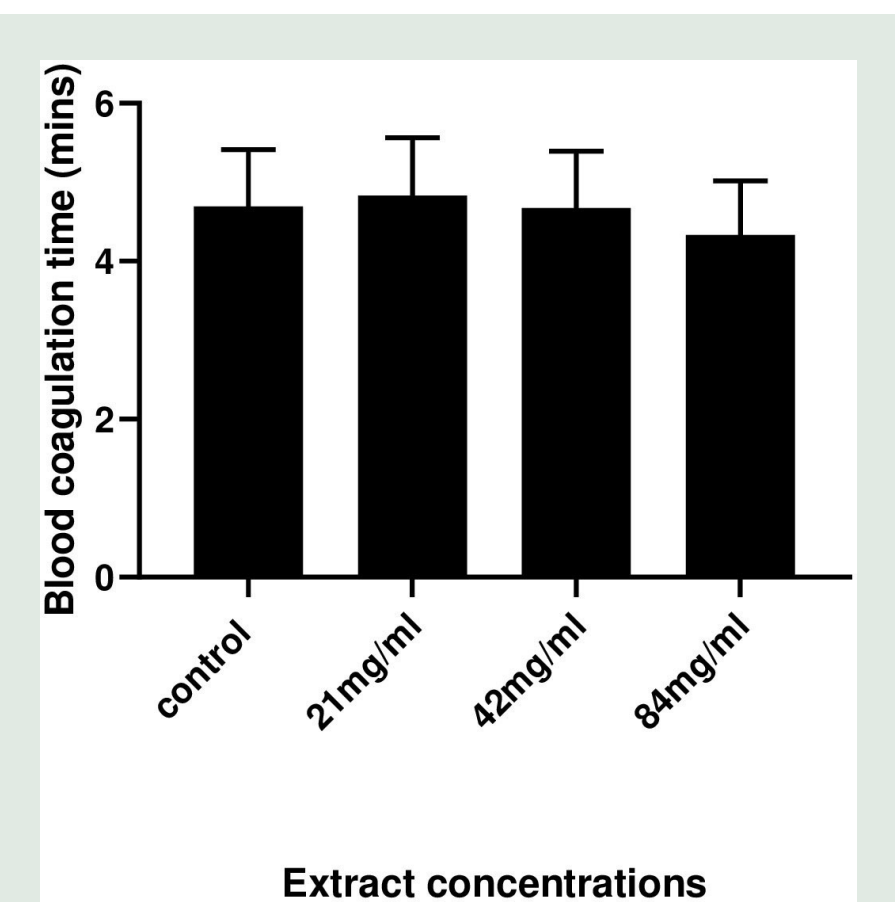

Figure 1: Effect of different concentrations of crude extract of B. pinnatum on whole blood coagulation time Showing the effect of crude extract of B. pinnatum concentrations, 21,42 and $84 \mathrm{mg} / \mathrm{ml}$, on whole blood coagulation time, with 84 $\mathrm{mg} / \mathrm{ml}$ concentration showing a reduction in human whole blood coagulation time. Values represent Mean $\pm S E M, n=5$.

Table 1: Effect of B. pinnatum concentrations on basic coagulation screening tests.

\begin{tabular}{cccccc}
\hline TEST & $\begin{array}{c}\text { Normal Saline + Plasma } \\
\text { + Reagent (control) }\end{array}$ & Plasma + Reagent & $\begin{array}{c}21 \mathrm{mg} / \mathrm{ml} \text { Extract + } \\
\text { Plasma + Reagent }\end{array}$ & $\begin{array}{c}42 \mathrm{mg} / \mathrm{ml} \text { Extract + } \\
\text { Plasma + Reagent }\end{array}$ & $\begin{array}{c}84 \mathrm{mg} / \mathrm{ml} \mathrm{Extract} \mathrm{+} \\
\text { Plasma + Reagent }\end{array}$ \\
\hline PT (sec) & $13.4 \pm 0.13$ & $13.4 \pm 0.049$ & $4.9 \pm 0.37^{*}$ & $1.68 \pm 0.16^{*}$ \\
PTTK (sec) & $42.5 \pm 0.045$ & $43.0 \pm 0.102^{*}$ & $30.5 \pm 0.60^{*}$ & $7.1 \pm 0.28^{*}$ & - \\
TT (sec) & $11.2 \pm 0.068$ & $10.7 \pm 0.106^{*}$ & $3.2 \pm 0.2^{*}$ & $1.06 \pm 0.19^{*}$ & - \\
ELT (min) & $96.5 \pm 1.05$ & $93.1 \pm 1.15^{*}$ & - & - & $81.0 \pm 1.3^{*}$ \\
\hline
\end{tabular}

Values represent Mean $\pm \mathrm{SEM}, \mathrm{n}=8 * \mathrm{P}<0.05$ compared to control

Effects of different concentrations of B. pinnatum crude extract on basic coagulation in-vitro screening tests: PT (Prothrombin time) in sec, PTTK (Partial Thromboplastin Time with Kaolin) in sec, TT (Thrombin Time) in sec, and ELT (Euglobulin lysis time) in mins. Values represent Mean \pm SEM, $\mathrm{n}=8 . \quad{ }^{*}$ represents $\mathrm{p}<0.05$ compared to control as significant. 


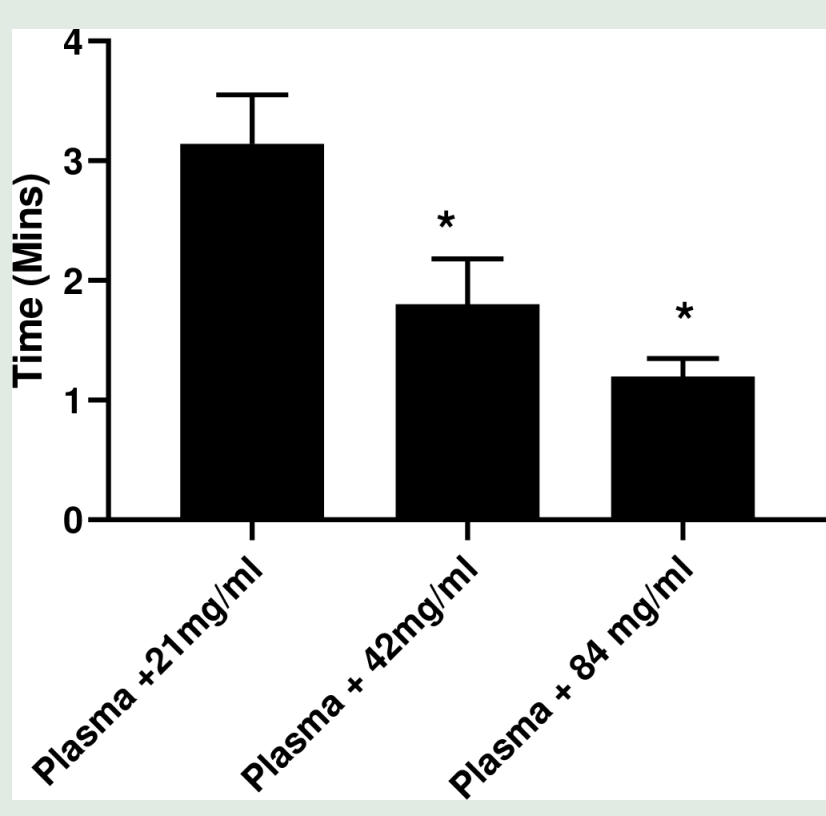

Figure 2: Effect of crude extract of B. pinnatum concentrations on plasma only coagulation

Showing the effect of crude extract of B. pinnatum concentrations, 21 , 42 and $84 \mathrm{mg} / \mathrm{ml}$, on plasma only coagulation, with 42 and $84 \mathrm{mg} / \mathrm{ml}$ concentrations showing significant reductions in plasma clotting time. Values represent Mean \pm SEM, $n=8 .{ }^{*}$ represents $p<0.05$ compared to control.

\section{Plasma clothing time}

In this study, plasma clothing time was examined with different concentrations of $B$. pinnatum extracts $(21,42$ and $84 \mathrm{mg} / \mathrm{ml})$ were added to plasma only. The clothing time was recorded in minutes. Concentrations of 42 and $84 \mathrm{mg} / \mathrm{ml}$ crude extract of $B$. pinnatum significantly reduced plasma-clothing time, as shown in Figure 2. Inferring that the extract has coagulant properties independent of the activating agents.

\section{Bleeding Time (BT)}

The results of extract $B$. pinnatum on bleeding time was performed on both whole blood as presented in Figure 3, produced a significant reduction with a $\mathrm{p}$ value of 0.0243 . This means that there is a significant difference between $B$. pinnatum treated and control with a reduction in bleeding time by $0.44 \mathrm{mins}$ (Figure 3 ).

\section{DISCUSSION}

The measurement of bleeding time, prothrombin time, thrombin, time, partial thromboplastin time with kaolin, Euglobulin lysis time are all screening tests of haemostasis. These are non-specific tests designed to assess overall haemostatic function and which are useful for the screening of patients who may have a bleeding disorder. In this present study, B. pinnatum crude extract was investigated for it is coagulating properties.

The prothrombin time test is a non - specific indicator of the extrinsic blood coagulation mechanism. Deficiencies of prothrombin and factors V, $\mathrm{VII}$ and $\mathrm{X}$ give rise to a prolonged bleeding time, as well as the presence of heparin in the blood and hypofibrinogenaemia. The present investigation using B. pinnatum crude extract, produced a reduced PT, indicating that the extract, has the potential to produce coagulation in a shorter time. Normal range of PT is $10-14$ secs. ${ }^{[34]}$ Partial Thromboplastin Time with Kaolin (PTTK), also known as the Activated Partial Thromboplastin

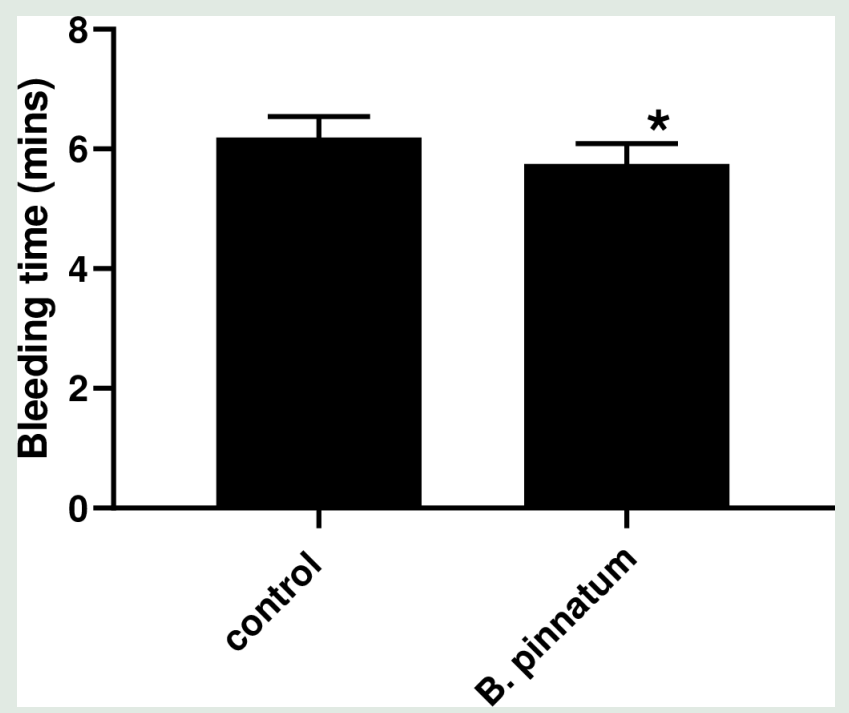

Figure 3: Effect of B. pinnatum concentration $(84 \mathrm{mg} / \mathrm{ml})$ on human bleeding time.

Showing the effect of crude extract of B. pinnatum concentration, $84 \mathrm{mg} / \mathrm{ml}$ on human bleeding time, showing significant reduction in human bleeding time. Values represent Mean $\pm S D, n=8$ with a *P value of 0.0243 compared to control.

Time (APTT) and the Kaolin - Cephalin Clotting Time (KCCT), is another blood screening test. It is a simple screening test for first stage plasma clotting factor deficiencies. When the results fall within normal range, it indicates normal clotting function. Reports has shown that PTTK is prolonged in deficiencies of factors XII, XI, X, IX, VIII, V or II. ${ }^{[35]}$ However, a normal PTTK result can be obtained with factor VII deficient plasma. Shorter than normal times have been reported in hyper- coagulable states as well as in cancer patients who are reported to develop shortened PTTK time. A condition of shortened PTTK, could make surgery difficult. The test is more useful in the detection of hemophilia A and B (Christmas disease). ${ }^{[36]}$ Severe hemophilia is usually described as frequent bleeding into the joints, muscles and soft tissues without any known cause. Also, patients with hemophilia can suffer from bleeding episodes that is life-threatening, like intracranial hemorrhages. ${ }^{[37]}$

In this study, we found that crude extract of B. pinnatum reduced PTTK time, indicating an activation of coagulation. Likewise, Ahmed et al. ${ }^{[34]}$ Reported that APTT normal time to be $34 \mathrm{sec}, B$. pinnatum crude extract gave a $30.5 \pm 0.60$ and $7.1 \pm 0.28 \mathrm{sec}$ respectively for 21 and $42 \mathrm{mg} / \mathrm{ml}$ concentrations.

Common causes of prolonged thrombin time (TT) include the presence of heparin, fibrinogen/fibrin degradation products, or depletion of fibrinogen. In chronic liver disease, the thrombin time is often prolonged and the clots are transparent and bulky. The defect is caused by abnormalities of fibrin polymerization. Abnormally polymerization is also the cause of a long thrombin time in some congenital dysfibrinogenaemia and in multiple myeloma. The thrombin time is usually a few seconds longer in plasma from new-born infants than in normal adult plasma. ${ }^{[38]}$ In this study, we observed a significantly reduced TT with extracts of B. pinnatum. $(1.06 \pm 0.19 \mathrm{sec})$ compared to the normal range of $17.3 \mathrm{sec} .^{[34]}$ Euglobulin Lysis Time (ELT) test measures predominantly plasminogen activator activity. The time for this activity was reduced by crude extract of B. pinnatum. Bleeding time is often prolonged in the condition of thrombocytopenia. A prolonged bleeding time is more likely with 
low platelet count due to defective bone marrow production than due to increased platelet deficiency. Other common cause of acquired platelet dysfunction is aspirin ingestion. Documented evidence show that aspirin could result in prolongation of the bleeding time up to $20 \mathrm{~min}$, and therefore a lower dose can affect the bleeding time. ${ }^{[39]}$ In this investigation, results show that different concentrations of the extract of $B$. pinnatum, non-significantly though, decreased the coagulation time compared with the control. However, the bleeding time was significantly reduced by the highest concentration of $84 \mathrm{mg} / \mathrm{ml}$, with a time of $5.75 \pm 0.342$. Bleeding and coagulation time tests are done to detect hemostatic disorders and when they are normal, it excludes hemostatic disorders. ${ }^{[40]}$ The extracts of $B$. pinnatum could be evaluated for use in hemostatic disorders such as uncontrolled bleeding. This study further supports the use of this plant extract in traditional medicine in stopping bleeding episodes.

\section{CONCLUSION}

The findings of the current study indicate that, the use of crude extract of B. pinnatum in bleeding episodes by traditional healers, has some merit and is well founded by the results presented here. Therefore, this plant extract has the potential to decrease bleeding time and affect overall blood coagulation process.

\section{ACKNOWLEDGEMENT}

I wish to acknowledge the assistance of the Department of Pharmacology, College of Medicine University of Lagos, Idi-Araba Lagos Nigeria. I also, extent my appreciation to $\mathrm{Mr} \mathrm{O}$. Adeleke of the Department of Pharmacognosy, for assisting in getting this plant material and its subsequent identification.

\section{CONFLICT OF INTEREST}

The author declares no conflict interest with this manuscript.

\section{ABBREVIATIONS}

APTT: Activated Partial Thromboplastin Time; BT: Bleeding time; ELT: Euglobulin Lysis Time; KCCT: Kaolin - Cephalin Clotting Time; PT: Prothrombin time; PTTK: Partial Thromboplastin Time with Kaolin; TT: Thrombin Time; WBCT: Whole blood coagulation time.

\section{REFERENCES}

1. Corns CM. Herbal remedies and clinical biochemistry. Ann Clin Biochem. 2003;40(5):489-507. doi: 10.1258/000456303322326407, PMID 14503986.

2. Ossei PPS, Appiah-Kubi A, Ankobea-Kokroe F, Owusu-Asubonteng G, Ayibor WG, Aninkora OK, Taylor J, Fenteng EA, Agyemang-Duah E, Agagli BM, Niako N. The culture of herbal preparations among pregnant women: A remedy or a suicide potion? A case report and mini review. Case Rep Pathol. 2020;2020:6186147. doi: 10.1155/2020/6186147.

3. Bent S. Herbal medicine in the United States: review of efficacy, safety, and regulation: grand rounds at University of California, San Francisco Medica Center. J Gen Intern Med. 2008;23(6):854-9. doi: 10.1007/s11606-008-0632-y, PMID 18415652.

4. Kaufman DW, Kelly JP, Rosenberg L, Anderson TE, Mitchell AA. Recent patterns of medication use in the ambulatory adult population of the United States: the Slone survey. JAMA. 2002;287(3):337-44. doi: 10.1001/jama.287.3.337. PMID 11790213

5. Ogunkunle AT, Oyelakin TM, Enitan AO, Oyewole FE. A quantitative documentation of the composition of two powdered herbal formulations (antimalarial and haematinic) using ethnomedicinal information from Ogbomoso, Nigeria. Evid Based Complement Alternat Med. 2014:2014:751291. doi: 10.1155/2014/751291.

6. Emeka PM, Badger-Emeka LI, Fateru F. In vitro antimicrobial activities of Acalypha ornate leaf extracts on bacterial and fungal clinical isolates. J Herb Med. 2012;2(4):136-42. doi: 10.1016/j.hermed.2012.09.001.

7. WHO (World Health Organization). Traditional medicine strategy 2002-2005; 2002. Available from: http://whqlibdoc.who.int/hq/2002/WHO_EDM_TRM_2002.1.pdf.

8. Mahady GB. Global harmonization of herbal health claims. J Nutr. 2001;131(3s):1120S-3S. doi: 10.1093/jn/131.3.1120S, PMID 11238830

9. Briggs WH, Folts JD, Osman HE, Goldman IL. Administration of raw onion inhibits platelet-mediated thrombosis in dogs. J Nutr. 2001;131(10):2619-22 doi: 10.1093/jn/131.10.2619, PMID 11584080.

10. Leta GC, Mourão PA, Tovar AM. Human venous and arterial glycosaminoglycans have similar affinity for plasma low-density lipoproteins. Biochim Biophys Acta. 2002;1586(3):243-53. doi: 10.1016/s0925-4439(01)00102-8, PMID 11997076.

11. Rajapakse N, Jung WK, Mendis E, Moon SH, Kim SK. A novel anticoagulant purified from fish protein hydrolysate inhibits factor XIla and platelet aggregation. Life Sci. 2005;76(22):2607-19. doi: 10.1016/j.Ifs.2004.12.010, PMID 15769484.

12. Satish A, Sairam S, Ahmed F, Urooj A. Moringa oleifera Lam.: protease activity against blood coagulation cascade. Pharmacogn Res. 2012;4(1):44-9. doi: 10.4103/0974-8490.91034, PMID 22224061.

13. Khan M, Patil PA, Shobha JC. Influence of Bryophyllum pinnatum (Lam.) leaf extract on wound healing in albino rats. J Nat Rem. 2004:4:41-6. doi: 10.18311/ jnr/2004/380.

14. Gwehenberger B, Rist $L$, Huch $R$, von Mandach U. Effect of Bryophyllum pinnatum versus fenoterol on uterine contractility. Eur J Obstet Gynecol Reprod Biol. 2004;113(2):164-71. doi: 10.1016/S0301-2115(03)00370-1, PMID 15063954

15. Gill LS. In The ethnomedical uses of plants in Nigeria. Vol. 143. Benin city, Edo State: University of Benin Press, University of Benin; 1992. p. 46.

16. Sharma AJ, Naresh C. Pharmacognostical studies of Bryophyllum pinnatum (Lam.) Kurz. Pharmacogn J. 2014;6(6):20-6. doi: 10.5530/pj.2014.6.5.

17. Burkill HM. The useful plants of West Tropical Africa. 2nd ed. UK: Royal Botanic Gardens, Kew; 1985. p. 130.

18. Fernandes JM, Cunha LM, Azevedo EP, Lourenço EMG, Fernandes-Pedrosa MF Zucolotto SM. Kalanchoe laciniata and Bryophyllum pinnatum: an updated review about ethnopharmacology, phytochemistry, pharmacology and toxicology. Revista Brasileira de Farmacognosia. 2019;29(4):529-58. doi: 10.1016/j.bjp.2019.01.012.

19. Akinpelu DA. Antimicrobial activity of Bryophyllum pinnatum leaves. Fitoterapia. 2000;71(2):193-4. doi: 10.1016/S0367-326X(99)00135-5.

20. Tamokou Jde D, Tala MF, Wabo HK, Kuiate JR, Tane P. Antimicrobial activities of methanol extract and compounds from stem bark of Vismia rubescens. J Ethnopharmacol. 2009:124(3):571-5. doi: 10.1016/j.jep.2009.04.062, PMID 19464353.

21. Ojewole J. Antihypertensive properties of Bryophyllum pinnatum \$lcurlb; (Lam) Oken\$rcurlb; leaf extracts. American Journal of Hypertension. 2002;15(4). doi: 10.1016/S0895-7061(02)02353-1.

22. Ghasi S, Egwuibe C, Achukwu PU, Onyeanusi JC. Assessment of the Medicinal benefit in the folkloric use of Bryophyllum pinnatum leaf among the Igbos of Nigeria for the treatment of Nigeria for the treatment of hypertension. Afr $J$ Pharm Pharmacol. 2011;5:83-92.

23. Yemitan OK, Salahdeen HM. Neurosedative and muscle relaxant activities of aqueous extract of Bryophyllum pinnatum. Fitoterapia. 2005;76(2):187-93. doi: 10.1016/j.fitote.2004.11.009, PMID 15752629.

24. Nguelefack TB, Sonita B, Alain BD, Dimo T, Kamanyi A, Vierling W. Spasmolytic effects of extracts from Kalanchoe crenata leaves. Pharmacol Line. 2006;1:30-9.

25. Sofowora A. Medicinal plants and traditional medicine in Africa. 3rd ed. Ibadan Spectrum Books Limited; 2008. p. 179-93.

26. Okwu DE, Josiah C. Evaluation of the chemical composition of two Nigerian medicinal plants. Afr J Biotechnol. 2006;5:257-361.

27. Ojewole JAO. Antinociceptive, anti-inflammatory and antidiabetic effects of Bryophyllum pinnatum (Crassulaceae) leaf aqueous extract. J Ethnopharmacol. 2005:99(1):13-9. doi: 10.1016/j.jep.2005.01.025, PMID 15848014

28. Quick AJ. The prothrombin time in haemophilia and in obstructive jaundice. $J$ Biol Chem. 1935:109:73-4.

29. Macpherson JC, Hardisty RM. A Modified Thromboplastin Screening Test Thromb Haemost. 1961;06(3):492-7. doi: 10.1055/s-0038-1654580.

30. Proctor RR, Rapaport SI. The partial thromboplastin time with kaolin. A simple screening test for first stage plasma clotting factor deficiencies. Am J Clin Pathol. 1961;36:212-9. doi: 10.1093/ajcp/36.3.212, PMID 13738153.

31. Hardistry RN, Ingram GIC. Bleeding disorders: investigations and Management. Oxford: Blackwell Scientific Publications; 1965. p. 320.

32. Blix S. Studies on the fibrinolytic system in the euglobulin fraction of human plasma. A. Methodological study. B. Application of the methods. Scand J Clin Lab Invest. 1961;13;Suppl 58:3-19. PMID 13870025.

33. de Brito Sousa JD, Sachett JAG, de Oliveira SS, Mendonça-da-Silva I, Marques HO, de Lacerda MVG, Fan HW, Monteiro WM. Accuracy of the Lee-White Clotting Time Performed in the Hospital Routine to Detect coagulopathy in Bothrops atrox Envenomation. Am J Trop Med Hyg. 2018;98(5):1547-51. doi: 10.4269/ajtmh.17-0992, PMID 29611503.

34. Ahmed R, Ganguli P, Singh N, Singh S, Gupta UD, Jaiswal Y, Asharaf Z, Reddy P, Nair $V$. Establishing reference ranges and normal values for coagulation screening in healthy Indian male volunteers enrolled for a longitudinal study. Biomed Biotechnol Res J. 2019;3(1):22-9. doi: 10.4103/bbrj.bbrj_140_18.

35. Shah SB, Bhageria V, Naithani BK, Bhargava AK. Unbelievable but true: partia thromboplastin time, kaolin $120 \mathrm{~s}$ and yet no surgical bleed! Indian Anaesth Forum. 2017;18(1):23-6. doi: 10.4103/ThelAForum.ThelAForum_8_17.

36. Gomez K, Bolton-Maggs P. Factor XI deficiency. Haemophilia. 2008;14(6):1183-9. doi: 10.1111/j.1365-2516.2008.01667.x, PMID 18312365. 
37. Castaman G, Matino D. Hemophilia A and B: molecular and clinical similarities and differences. Haematologica. 2019;104(9):1702-9. doi: 10.3324/haematol. 2019.221093, PMID 31399527.

38. Dacie JV, Lewis SM. Investigation of the haemostatic mechanism. Practical haematology. 6th ed. Churchill Livingstone; 1979. p. 217-20.
39. Mielke CH Jr, Kaneshiro MM, Maher IA, Weiner JM, Rapaport SI. The standardized normal Ivy bleeding time and its prolongation by aspirin. Blood. 1969;34(2):204-15. doi: 10.1182/blood.V34.2.204.204, PMID 5794116.

40. Narang $V$, Sharma K, Sood N. Bleeding time/Clotting time: its Time to Change. Indian J Surg. 2020;82(6):1328-. doi: 10.1007/s12262-020-02312-w.

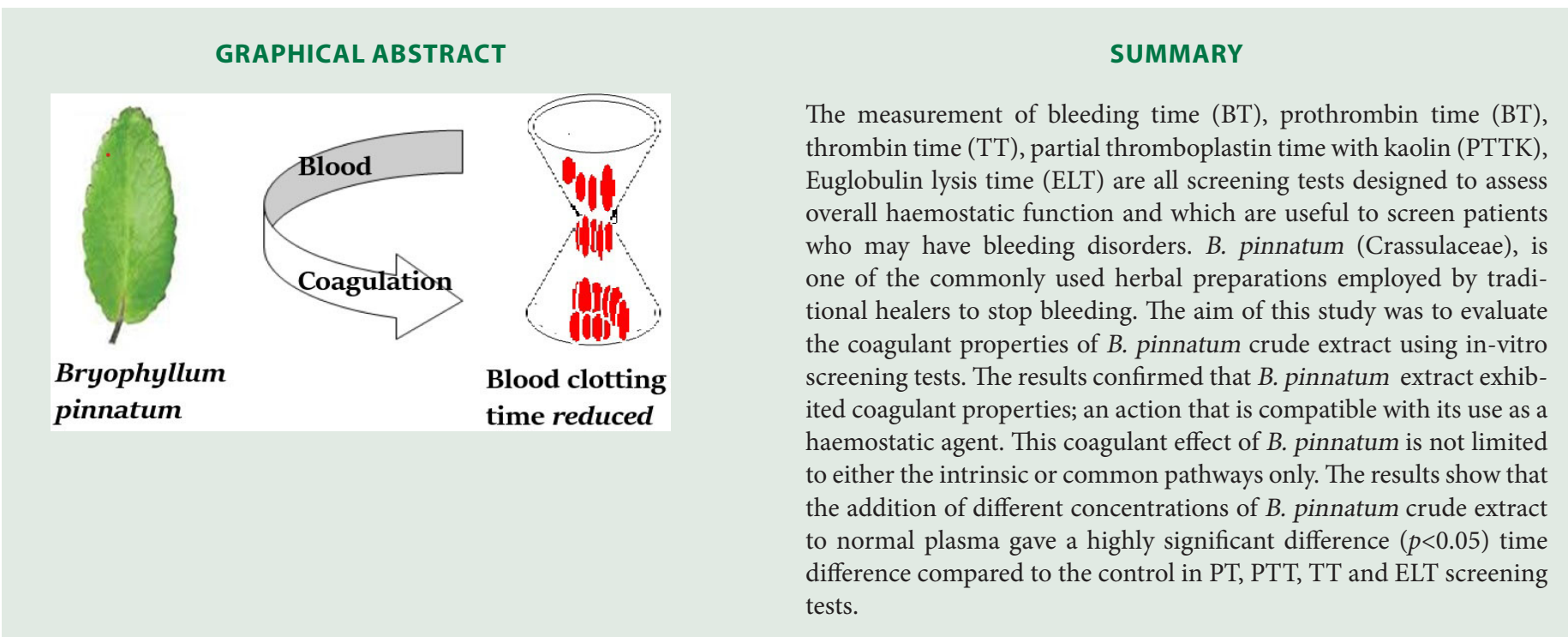

Cite this article: Emeka PM. In-vitro studies of Bryophyllum pinnatum Crude Extract on Blood Coagulation Indices: An Investigation on its Traditional Medicine Use. Pharmacog Res. 2021;13(4):268-73. 